\title{
A FELNŐTTKORI HIPNOTIKUS FOGÉKONYSÁG FEJLÔDÉSI ÉS SZOCIALIZÁCIÓS MEGHATÁROZÓI
}

\author{
KÖLTÖ ANDRÁS ${ }^{1,2}$ - JÓZSA EMESE - BÁNYAI ÉVA ${ }^{1}$ \\ ${ }^{1}$ ELTE Eötvös Loránd Tudományegyetem Pszichológiai Intézet \\ ${ }^{2}$ National University of Ireland Galway, Health Promotion Research Centre \\ E-mail: andras.kolto@nuigalway.ie
}

Beérkezett: 2018. december 4. - Elfogadva: 2019. január 27.

\begin{abstract}
A kliens és a terapeuta közötti hipnoterápiás kapcsolat sok szempontból hasonlit a gyermek-szüló viszonyra. A hipnózis szociál-pszichobiológiai megközelitésében a felnôttkori hipnotikus fogékonyság mértékét az idegrendszer fejlödése és a szocializációs folyamatok is befolyásolják. Ennek ellenére eddig nagyon kevés kutatás foglalkozott a felnôttkori hipnotikus fogékonyság fejlôdési elözményeivel. Szintén kevés vizsgálatot végeztek a szocializációs hatások feltárására; a gyermekkori emlékeket ezekben is inkább kvalitatív módszerekkel tanulmányozták. Ebben a cikkben összefoglaljuk e kutatások fóbb eredményeit, majd bemutatjuk kutatócsoportunk 2008 óta végzett vizsgálatait, amelyekben a szülöi nevelési stílusra vonatkozó emlékek és a felnôttkori hipnotikus válasz összefüggéseit kerestük. Standardizált, kvantitatív méróeszközöket alkalmazó keresztmetszeti vizsgálataink tanulsága, hogy a hideg-büntetố szülói nevelési stílus elôrejelzi a laboratóriumi hipnózisban átélt negatív érzelmeket és a hipnotizốr rosszallásától való félelmet. Ezt a kapcsolatot részben az alexitímiás érzelemfeldolgozás mediálja. Ezek az eredmények segítséget adhatnak a hipnoterápia megtervezéséhez és a teherbíró pszichoterápiás szövetség kialakításához.
\end{abstract}

Kulcsszavak: szülói nevelési stílus, szülôi viselkedés, hipnábilitás, hipnotikus fogékonyság 


\section{BEVEZETÉS}

A hipnotikus interakció résztvevôi - az alany és a hipnotizôr - között még a látszólag semleges, laboratóriumi környezetben és kutatási céllal végzett, kötött forgatókönyvú hipnózisban is olyan kapcsolat jöhet létre, amely sok vonatkozásban hasonlít a gyermek-szüló viszonyhoz. Ez a hasonlóság megjelenhet mind a viselkedés, mind a hipnotikus élmények és az áttételi-viszontáttételi érzelmek, mind a pszichofiziológiai változások szintjén. Ennek ellenére kevés kutatást végeztek annak feltárására, hogy a szülôkkel kapcsolatos gyermekkori emlékek milyen kapcsolatban állnak a felnôttkori hipnotikus válasz dimenzióval, s az ezzel kapcsolatos empirikus bizonyítékok java része is egy öt évtizede elvégzett, nagy elemszámú kvalitatív kutatásból (J. R. Hilgard, 1979) származik. Olyan longitudinális vizsgálat pedig tudomásunk szerint egyáltalán nincs, amely a vizsgálati személyeket és szüleiket a személyek születésétôl kezdve tanulmányozná, hogy a gyermek-szüló interakció jellegzetességeit összevesse a személyek felnôttkori hipnotikus reakcióival. Az eddig ismert determinánsok - pszichogenetikai tényezôk, személyiségvonások, figyelmi kapacitás és egyes felnôtt kötôdési mintázatok - mellett a szülôi nevelés is hozzájárulhat a felnôttkori hipnábilitásban megfigyelt változatossághoz. A hipnoterapeuta munkáját is segítheti, ha felméri a kliens szülôkkel kapcsolatos emlékeit és élményeit, mert ezek befolyásolhatják a terápiás munka minóségét.

Ebben a tanulmányban áttekintjük azokat az idegtudományi eredményeket és (elsôsorban kvalitatív) kutatásokat, amelyekben a szülői viselkedés felnôtt hipnotikus fogékonyságra gyakorolt befolyását vizsgálták. Ezután összefoglaljuk saját, standard kérdôíveket és hipnábilitási skálákat alkalmazó vizsgálatainkat, amelyek megerôsítették, hogy a szülôii nevelésre vonatkozó emlékek elôrejelzik a felnôttkori hipnotikus válasz dimenzióit, fôleg bizonyos hipnózisbeli élményeket és áttételi érzelmeket. Végül kitérünk a jövôbeli lehetséges kutatási irányokra és eredményeink gyakorlati felhasználhatóságára.

\section{HIPNÓZISSTÍLUSOK ÉS ARCHAIKUS BEVONÓDÁS}

Már maga Freud leírta a hipnoterápiás kapcsolat és a szülő-gyerek viszony hasonlóságát (Bachner-Melman és Lichtenberg, 2001), Ferenczi (1909/2002) pedig „anyai” és „apai” hipnózistípusokat különített el. Korábbi vizsgálataink igazolták, hogy ezeket a hipnotizốrök tudattalanul még a látszólag semleges, hipnotikus fogékonyság standard körülmények között történô felmérésére végzett hipnózisok alatt is alkalmazzák (Bányai, 1998, 2002).

A hipnózis pszichoanalitikus megközelítése a hipnotizált személy és a hipnotizôr közötti áttételi-viszontáttételi érzelmi kapcsolatot az archaikus bevonódás fogalmával írja le. Az alanyban a hipnotizórról kialakuló reprezentáció gyakran leképezi azokról a tekintélyszemélyekrôl - leggyakrabban a szülookrôl - alkotott modelleket, akik fontos szerepet játszottak korai életében. Shor (1962) ezt tekinti az archaikus bevonódás alapjának. 
A korai tárgykapcsolatokban kialakított kötôdési munkamodell (Bowlby, 1979/2005) és a szülôk viselkedésével kapcsolatos élmények tehát akár késô felnôttkorban is befolyásolhatják a hipnotikus bevonódást. Emiatt a hipnotikus interakció múködésének jobb megértéséhez figyelembe kell vennünk a személyek gyermekkori élményeit.

\section{A CSECSEMŐKORI KÖTŐDÉS ÉS AZ IDEGRENDSZERI FEJLŌDÉS SZEREPE}

A korai kapcsolatok befolyásolják a szelf fejlôdését és az énreprezentációk kialakulását. A csecsemô- és kisgyermekkorban átélt összehangolódási élmények szolgáltatnak idegrendszeri alapot az interszubjektivitáshoz, az önszabályozáshoz és a késôbbi - felnốttkori - interakciós szinkronitáshoz (Bányai, 2008). A dajkálás, ringatás, a csecsemô és a kisgyermek érzelmi-mentális állapotainak jelölése, visszatükrözése (Gergely és Watson, 1996) magas interakciós szinkronitásra hangolja a központi idegrendszert (Bányai, 2008). Így a csecsemó- és kisgyermekkori élmények áttételes módon a hipnotikus interakcióba való bevonódás képességét is befolyásolhatják.

A csecsemô kötôdési mintázatai és a felnôttkori hipnotikus válasz közötti kapcsolatot írja le Posner és Rothbart (2011) elmélete. Szerintük a csecsemókor során kialakuló érzelmi és kognitív (ön) kontroll egyértelmúen összefügg a szülők viselkedésével, és a kapcsolatot a központi idegrendszer orientációs folyamatai jelentik. Gyakori szülôi stratégia a nyugtalan, síró csecsemô megnyugtatására egy addig ismeretlen tárgy mutatása (Harman, Rothbart és Posner, 1997). Ez a csecsemô agyában aktiválja az anterior gyrus cingulumot (ACC) és más, a végrehajtó figyelmi hálózatban szerepet játszó agyterületeket, amelyek egymással szoros kölcsönhatásban fejlődnek (Posner, Rothbart és Voelker, 2016). Az ACC és a végrehajtó figyelmi rendszerek szerepe a hipnózisban többszörösen bizonyított. A hipnózisbeli módosult tudatállapot, sốt még a hipnábilitás is összefügg az ACC módosult aktivitásával (Faymonville, Boly és Laureys, 2006; Gruzelier, 2006; Hoeft és mtsai, 2012). Úgy tûnik, ezt az aktivitásváltozást maga a hipnotikus szuggesztió okozza (Raz, Fan és Posner, 2005; Raz, Shapiro, Fan és Posner, 2002). A hipnózis erôs hatást gyakorol a korábban kifejlődött orientációs hálózatra, de gyengébbet a késôbb kifejlődô végrehajtó hálózatra, ennek eredményeképpen „a fogékony személy [hipnózisban] könnyebben kerül »külsố kontroll« hatása alá. Ahogy a korai életszakaszban a gyermek kontrollja a szülő kezében van, hipnózis során a felnôtt személy kontrollját a hipnotizőr veszi át” (Posner és Rothbart, 2011, 3.). A megnyugtatásra alkalmazott figyelmi reorientációs „trükk” révén pedig a csecsemó agya nagyobb eséllyel fejlôdik úgy, hogy a figyelmi hálózat felnôttkorban is aktívan reagáljon a külsô ingerekre, így a hipnotizőrtôl érkezô szuggesztiókra.

Mindez arra utal, hogy a meleg és szeretetteljes szülői viselkedés, a csecsemó igényeire és érzelmi állapotára való odafigyelés és a megnyugtatására tett kísérletek (amelyek a biztonságos kötôdési stílus jelzôi) magasabb felnôttkori hipnábilitáshoz vezethetnek. A bizonytalanul kötôdô csecsemôknél - a biztonságos kötôdési stílussal jellemezhetố csecsemôkhöz képest - alacsonyabb bal agyféltekei frontális aktivitást mutattak ki (Lakatos és Gervai, 2003), ami megalapozhatja az alacsony felnôttkori hipnotikus fogékonyságot (Bányai, 2015). Igaz, ezeket a kapcsolatokat a szocializáció 
és a késôbbi életesemények, például traumatikus élmények (Butler, Duran, Jasiukaitis, Koopman és Spiegel, 1996) vagy a korrektív pszichoterápia (Beauregard, 2014) elfedhetik vagy akár meg is szüntethetik.

\section{FEJLÔDÉSI „ÖSVÉNYEK”}

A szülőkkel kapcsolatos emlékek és a felnôttkori hipnábilitás kapcsolatára vonatkozó empirikus bizonyítékok alapja J. R. Hilgard (1979) és munkatársai kevert módszerú kutatása. Ôk összesen 839 személlyel készítettek félig strukturált interjút, mielôtt a Stanford Hipnotikus Szuszceptibilitási Skála C változatával (SHSS:C) (Weitzenhoffer és Hilgard, 1962) felmérték hipnábilitásukat, 146 személlyel pedig a skála alkalmazása után készítették el az interjút. Utóbbiakat hipnózisbeli élményeikrôl is kikérdezték.

J. Hilgard feltételezte, hogy a gyermekkorban átélt, erôs képzeleti bevonódással járó helyzetek magas felnốttkori hipnábilitáshoz vezetnek. Az interjúban rákérdeztek a vizsgálati személyek gyermekkori családjának összetételére; az apával és anyával való kapcsolatra; a szülők jutalmazó és büntetô módszereire; a gyermekkori szabadidôs tevékenységekre.

Azok a személyek, akik gyermekkorukban gyakran merültek el erôs képzeleti bevonódást igénylő tevékenységekben (pl. olvasás, fantáziálás, képzeletbeli barátok, mesevagy regényhôsökkel való azonosulás stb.), nagyobb eséllyel voltak közepesen vagy erôsen hipnábilisak. Azok, akik nem vagy csak ritkán éltek át képzeleti bevonódást gyermekkorukban, inkább az alacsony hipnábilitási övezetbe estek.

Két tipikus fejlôdési „ösvény” határozta meg az erôs képzeleti bevonódást. Azok, akik arról számoltak be, hogy szüleik meleg és szeretetteljes kapcsolatban voltak velük, gyakran megfigyelték, hogy maguk a szülôk is erôsen bevonódnak efféle tevékenységekbe (pl. olvasás, tévénézés, kertészkedés vagy más hobbi). Ezek a gyerekek az érzelmi ragály és a szülôkkel való azonosulás révén lettek fogékonyak az erôs képzeleti bevonódásra. A másik jellegzetes mintázat azoké volt, akik érzelmileg hideg és elérhetetlen, illetve gyakori és kemény büntetést (pl. testi fenyítést) alkalmazó szülőket idéztek fel. Ôk a képzeleti bevonódást igényló tevékenységeket menekülési stratégiaként használták. Felnôttkorukban is erôsebb bevonódásról, élénkebb fantáziaképekrôl számoltak be.

Magasabb pontszámot értek el az SHSS:C skálán azok a személyek, akiknek gyermekkorukban volt képzeletbeli barátja vagy segítôtársa. J. Hilgard a „mintha”-játékokat is a hipnotikus jelenségek elóképének tekinti. A képzeletbeli barátok vagy játszótársak sokszor olyan funkciót látnak el, mint amit Winnicott (1953) az átmeneti tárgyaknak tulajdonít. Lehetséges, hogy azok a gyerekek, akik ilyen belsô átmeneti tárgyakat használnak, késôbb nagyobb eséllyel képesek bevonódni a hipnózisba, amely pszichoanalitikus szempontból szintén értelmezhetô „átmeneti térként” (Baker, 2000). Ez teszi lehetôvé, hogy hipnoterápiás helyzetben a kliens a tanult viselkedés automatizmusából kilépve gondolatban más lehetôségeket, megoldási módokat is kipróbáljon, és így gazdagítsa viselkedésrepertoárját (Bányai, 2015).

Ezeknek az eredményeknek az alapján J. Hilgard megfogalmazta a hipnózis „fejlôdési ösvények" elméletét. A modell alapvetése, hogy a gyermekkorban átélt bevonó- 
dás magasabb felnôttkori hipnábilitáshoz vezet. A bevonódás mélységét és intenzitását pedig nagy részben a szülối viselkedés, és a szeretetteljes szülókkel való azonosulás, vagy a hideg-büntetố szülôktôl való félelem alapozza meg. Elméletével összhangban, az interjúk alapján kiszámított pontszámokkal mért szülói melegség, illetve büntetés kb. $r=0,20-0,30$ erôsségú korrelációt mutatott az SHSS:C hipnábilitási pontszámmal. Érdekes ugyanakkor, hogy több, gyakori büntetést és hideg-elutasító szülóket felidézô vizsgálati személy is kifejezte az elôzetes interjúk során, hogy szeretne jó „hipnotikus alany" lenni. Ez felveti, hogy a viselkedéses hipnábilitás mellett az is fontos lehet, hogy az alanyoknak milyen elvárásaik vannak a hipnózissal kapcsolatban, milyen élményeket élnek át hipnózisban, és milyen személyközi kapcsolatot alakítanak ki a hipnotizôrrel.

\section{A GYERMEKI HIPNÁBILITÁS ÉS A SZÜLŐI STÍLUS HATÁSÁNAK KVANTITATÍV VIZSGÁLATA}

A gyermekek fogékonyabbak a hipnózis iránt, mint a felnôttek (London, 1965; Morgan és Hilgard, 1973), aminek a gyerekek mindennapi életében gyakran elóforduló spontán fantáziajátékok és álmodozás lehet az alapja (Gardner, 1974; Gardner és Olness, 1981). A fókuszált koncentráció, a korlátozott valóságellenôrzés, a konkrét (és mágikus) gondolkodás, az érzelmi nyitottság az új élmények iránt - beleértve a regresszív állapotokat is - és az érzelmi intenzitás miatt a gyerekek „természetes” magas fogékonyságú hipnotikus alanyok. S ahogy azt J. Hilgard vizsgálatai és késôbbi empirikus munkák is mutatják, a felnôtt tekintélyszemélyek viselkedése, hipnózissal vagy más disszociatív állapotokkal kapcsolatos attitúdje felerôsítheti ezt a hatást (Rhue, 2004).

A kisgyermekkorban átélt hipnózis funkcionálisan és kognitív-érzelmi szabályozás tekintetében is eltér a nagyobb gyerekek és felnôttek hipnózisától. Míg utóbbiak saját akaratukból, a hipnotizôrrel együttmúködve vonódnak be a hipnotikus állapotba, addig a kisebb gyerekeknél a bevonódás fó hatótényezóje a tekintélyszemélyre irányuló figyelem és az általa gyakorolt kontroll szintje. Ezért a kisgyermekek hipnózisát J. R. Hilgard és Morgan (1978, 286.) protohipnózisnak nevezi: „A nagyon fiatal gyerekek inkább képesek arra, hogy figyelmüket egy történet mesélésével eltereljük, mint hogy [a fájdalmas orvosi beavatkozástól, hipnoterápiás vagy önhipnotikus szuggesztiókkal] saját fantáziájukat használva távolítsák el magukat.” A protohipnózis és az érett hipnózis közötti váltás kisiskoláskorban, 5-7 éves kor körül következik be. Vandenberg (2002) hangsúlyozza, hogy ebben a korban alakulnak ki a gyermekek „metamentális” készségei, amelyek megfelelnek más szerzók, például Fonagy és munkatársai (Fonagy, Bateman és Bateman, 2011; Fonagy, Steele, Steele, Moran és Higgitt, 1991) mentalizáció-értelmezésének. Ide tartozik a saját gondolkodásunkra és a szociális kapcsolatokra való reflektálás, a mentális aktivitás önszabályozása. Vanderberg szerint ezekhez köthetô, hogy az idôsebb gyerekek és a felnôttek képesek a hipnotikus interakcióban való tudatos részvételre.

A fent említett példákat leszámítva a hipnóziskutatás irodalmában ritkák a fejlôdési háttérrel foglalkozó kutatások. A J. Hilgard szülôi nevelésre vonatkozó kvalitatív eredményeinek kvantitatív módszerekkel való megerôsítésére az általunk ismert egyetlen példa Rhue és Lynn vizsgálata (Lynn és Rhue, 1988; Rhue és Lynn, 1987). Ôk a fan- 
táziálásra hajlamos személyiség fejlôdési elốzményeit keresték, valamint azt vizsgálták, hogy ezek hogy függenek össze fiatal felnôttek hipnábilitásával. A fantáziálásra hajlamos személyek gyakoribb és keményebb gyerekkori büntetésrôl (testi fenyítésrôl) számoltak be, mint azok, akiknek alacsony volt a képzeleti aktivitása. A gyakran büntetett személyek - összhangban J. Hilgard megfigyeléseivel - a képzeletet gyakran menekülési, megküzdési stratégiaként alkalmazták. Ugyanakkor a két csoport között nem volt különbség abban a tekintetben, hogy szüleiket mennyire látták szeretetteljesnek, ami rámutat arra, hogy a szülöi büntetés és az érzelmi melegség nem feltétlenül zárja ki egymást. A szerzốk különbözô mérôeszközök alkalmazásával megerôsítették a szülối büntetés, a fantáziakészség és a felnôttkori hipnábilitás kapcsolatát. Rhue (2004) azonban az erôs felnôttkori hipnábilitás fejlôdési determinánsairól szóló tanulmányában maga is hangsúlyozza, hogy ezen a területen nagy szükség lenne további kvantitatív vizsgálatokra.

\section{A FEJLŐDÉS ÉS A SZOCIALIZÁCIÓ A HIPNÓZIS SZOCIÁL-PSZICHOBIOLÓGIAI MODELLJÉBEN}

Az elsô olyan hipnóziselmélet, amely figyelembe vette a kora gyermekkori élményeket, a fejlôdési-interaktív modell volt. E szerint az elképzelés szerint a velünk született képességeket a fejlôdés során élettapasztalatok - így a szocializáció - befolyásolják, így azokat a hipnotikus válasz elemzésekor is figyelembe kell venni. Az interaktív jelleg pedig arra vonatkozik, hogy a velünk született és fejlôdés során szerzett hatások egymással kölcsönhatásban alakítják a felnôttkori hipnotikus fogékonyságot (E. R. Hilgard, 1965).

Ezen az általános fejlôdésalapú megközelítésen túl azonban az eddigi elméleti modellek közül egyedül a szociál-pszichobiológai megközelítés integrálja a fejlôdés-idegtudományi és szocializációs elôzményeket a felnôttkori hipnábilitás magyarázatába. Bányai (2008; valamint Bányai tanulmánya a jelen tematikus számban, pp. 7-26.) megközelítésében a hipnózis és a hozzá hasonló módosult tudatállapotok olyan, evolúciós szempontból hasznosnak bizonyult személyközi interakciók, melyeknek kölcsönös ingerbemenet-szabályozó szerepe révén mindkét résztvevốre jótékony hatása van. Az interakcióban való részvétel azonban rugalmasságot kíván meg mind az alany, mind a hipnotizôr részérôl. Ezt a rugalmasságot a csecsemô és az elsốdleges gondozó, elsôsorban az anya (késôbb a kisgyermek és szülei, testvérei) közötti kötôdésre lehet visszavezetni. A csecsemó, kisgyermek arousalszintjének empatikus átvétele és modulációja hozzásegíti ốt ahhoz, hogy belsô ritmusát fokozatosan a társas környezethez igazítsa. Az érzelemtükrözés és -jelölés (Fonagy, Gergely, Jurist és Target, 2002; Gergely és Watson, 1996) pedig az érzelmek tudatosulását és az önkontrollt segítik elô, hozzájárulnak ahhoz, hogy a szelf önszabályozó ágenssé váljon. A korai kapcsolatok minôsége a figyelmi orientációt, az ingerszelekciót, a stresszel való megküzdést is befolyásolja.

A hipnózis olyan átmeneti helyzet, amely kedvez a résztvevook gyors egymásra hangolódásának. A hipnotizôr az indukció során az alany aktivációs szintjének csökkentésére vagy növelésére törekszik, s figyelmét a környezet figyelemelvonó ingereirôl saját testi folyamataira, belsố történéseire irányítja (Bányai, 2008). Ebben az „ingercsökkentett" helyzetben a hipnotizôr és az alany figyelme egyre jobban egymásra irányul, 
az interakciós partnertôl érkezó szociális ingerek egyre nagyobb szerepet kapnak a helyzet irányításában. A hipnotizôr folyamatosan visszajelzi az alany kívülrôl megfigyelhetố viselkedéses megnyilvánulásait és a pszichofiziológiai változások (pl. a relaxált állapot) jeleit, amivel tulajdonképpen ugyanazt a funkciót tölti be, mint a szülói, érzelemtükrözó és -jelölő „szociális biofeedback” (Gergely és Watson, 1996).

A hipnotikus fogékonyság ebben az elméletben annak a rugalmasságnak a mutatója, hogy milyen könnyen lép be az alany a szoros személyközi interakcióba, amelyben a kölcsönös szabályozó mechanizmusok révén hipnotikus módosult tudatállapotba kerül. A felnôttkori hipnotikus fogékonyság Bányai (2008) szerint a szocializációs folyamatban alakul ki, így a szülókkel való kapcsolat minôsége, a szülôk viselkedése és kommunikációs stílusa befolyásolja annak szintjét. Ezt J. R. Hilgard (1979) eredményei mellett saját, kvantitatív módszereket alkalmazó vizsgálataink is megerôsítették.

\section{KÉRDÔÍVES VIZSGÁLATOK AZ ELTE HIPNÓZISKUTATÓ LABORATÓRIUMÁBAN}

Kutatócsoportunk 2008 óta szisztematikus vizsgálatokat végez annak ellenôrzésére, hogy a hipnábilitás multidimenzionális magyarázatához hozzájárul-e a szülői nevelési stílus. A hipnózis többdimenziós jellegének eddigi legátfogóbb kutatását Lichtenberg, Bachner-Melman, Ebstein és Crawford (2004) végezte. Ők többszörös regresszióelemzéssel megállapították, hogy a kitartás személyiségvonás, a fókuszált figyelem, az abszorpció és a katekol-O-metiltranszferáz enzim genetikai polimorfizmusa az SHSS:C skálával mért hipnábilitás 33,6\%-át magyarázza. Az itt összefoglalt vizsgálatokban arra kerestük a választ, hogy a szülókre vonatkozó emlékek hozzátesznek-e a hipnotikus fogékonyság magyarázatához. A fogékonyság alatt - a szociál-pszichobiológiai elmélettel összhangban - nemcsak a hipnózismélység-mérô viselkedéses skálákon elért hipnábilitási pontszámot, de az alany által átélt archaikus bevonódás (Bányai, Varga és Gôsiné Greguss, 2001) és a tudatállapot módosulásával járó jellegzetes élménymintázat (Varga, 2017) erôsségét is értjük.

\section{Szülöi nevelési stílus és hipnotikus fogékonyság}

Összhangban J. R. Hilgard (1979) „fejlôdési ösvények” elméletével, feltételeztük, hogy a szülôi melegségre és hideg-büntetô viselkedésre vonatkozó emlékek alacsony-közepes mértékben, de szignifikánsan elôrejelzik a felnôttkori hipnábilitást. Kutatócsoportunk többdimenziós hipnózisfelfogására és korábbi eredményeire alapozva (ld. Bányai, Józsa és Költô, pp. 45-61., illetve Varga tanulmányait a jelen tematikus számban, pp. 95-112.) feltételeztük, hogy az alany által felidézett szülối nevelési stílus összefügg a hipnózisban mutatott archaikus bevonódással és a módosult tudatállapot jellegzetes élményeivel. Egyes eredmények (pl. Varga és Kekecs, 2014), illetve Kasos és munkatársai jelen tematikus számban (pp. 79-93.) bemutatott pszichoendokrin vizsgálatai is azt sugallják, hogy e két dimenzió erôsebben összefügg a szülookre vonatkozó emlékekkel, mint a viselkedéses hipnábilitás. 
A viselkedéses hipnábilitást a Shor és Orne (1962) által kifejlesztett Harvard Hipnábilitási Csoportskálával (HCsS, magyar változat: Költô, Gôsi-Greguss, Varga és Bányai, 2015) és Bowers (1993) Waterloo-Stanford Hipnábilitási Csoportskálájával (WSGC) (magyar változat: Gôsiné Greguss, 1999) mértük. A hipnotizôrhöz fúzôdô érzelmi kapcsolatot az Archaikus Bevonódási Skálával (ABS, l. a jelen tematikus számban Bányai és mtsai tanulmányát, pp. 45-61.), a módosult tudatállapotra jellemzó élményeket a Tudat Fenomenológiája Kérdôívvel (PCI, l. a jelen tematikus számban Józsa és mtsai tanulmányát, pp. 27-43.) vizsgáltuk. A szüloói nevelési stílus mérésére az eredetileg Svédországban kifejlesztett Emlékeim a Szülooi Nevelésrôl (EMBU) kérdôív rövidített, 23 tételes változatát (Arrindell és mtsai, 1999) alkamaztuk. Az EMBU tételeivel való egyetértést az apára és az anyára vonatkozóan négyfokú Likert-skálán jelölik a személyek. A tételek három faktorba rendezôdnek, amelyet az anyára és az apára vonatkozóan külön számolunk ki: 1. Elutasítás, 2. Érzelmi melegség, 3. Túlvédés. Hogy a J. R. Hilgard (1979) által leírt, büntetéssel kapcsolatos összefüggéseket vizsgálni tudjuk, az EMBU megfelelő tételeiból (amelyek a testi fenyítésre, a gyermek megszégyenítésére, egyes tevékenységek tiltására vonatkoztak) kialakítottunk egy kiegészítő, operacionális skálát: 4. Büntetés (Költô, 2008). A kérdôívhez csatoltunk néhány, a családi struktúrára vonatkozó kérdést (Költô, 2015).

A 2008 és 2015 közötti idôszakban két vizsgálatban összesen 438 egészséges felnôtt személyt vizsgáltunk meg (Költô, Józsa és Bányai, in press). Az elsố vizsgálatban részt vevô 196 személy átlagéletkora 23,93 \pm 4,96 év, a nôk aránya 65\%. A második vizsgálatban 246 személy szerepelt (átlagéletkoruk 28, $26 \pm 9,63$ év), a nôk aránya $55 \%$ volt. A személyek kitöltötték az EMBU kérdőívet, illetve szakemberek által vezetett, standard laboratóriumi csoporthipnózison vettek részt. Az egyik vizsgálatban a WSGC-t, a másikban a HCSs-t alkalmaztuk a hipnábilitás mérésére. A hipnózist követôen a személyek kitöltötték az ABS és PCI kérdôívet. Az összefüggések ellenôrzésére korrelációs vizsgálatokat és többszörös lineáris regresszióelemzést végeztünk. Az öszszehasonlítások nagy száma miatt a korrelációs együtthatók kiszámításakor bootstrapping technikát alkalmaztunk, amely az elsôfajú hiba felhalmozódását is kiküszöböli. A vizsgálatok részletes módszerét, valamint az eredményeket Költő és munkatársai (in press) közlik. Az 1-2. táblázatban összefoglaljuk a két vizsgálatban lineáris regresszióelemzéssel nyert eredményeket.

A táblázatokról leolvasható, hogy a szülôii nevelési stílusra - elsôsorban a büntetô-kontrolláló viselkedésre és az érzelmi melegség (hiányára) - vonatkozó emlékek szignifikáns elốrejelzối a hipnotikus válasznak, bár a szülői nevelés által megmagyarázott változatosság szintje alacsony (3-22\% közötti). Különbségeket találtunk a két vizsgálat között, illetve a vizsgálati személyek neme szerint. Általánosságban azonban elmondható, hogy a szülők büntetô-elutasító viselkedése összefügg a hipnózisban átélt negatív érzelmekkel (az ide tartozó PCI-tételek magukba foglalják a feszültséget, dühöt, félelmet és szomorúságot), és a hipnotizốr iránt érzett (negatív vagy pozitív színezetû) áttétellel. Érdemes kiemelni, hogy az elsô vizsgálatban az anyai büntetés a férfiak negatív archaikus bevonódásának 17,7\%-át, a szülook büntetô viselkedése a hipnotizôr haragjától, rosszallásától való félelem 21,9\%-át, míg a második vizsgálatban a szülőkre vonatkozó emlékek (elsôsorban az anya viselkedése) a nôk hipnózis alatti negatív érzelmeinek 19,3\%-át megmagyarázta úgy is, hogy más magyarázó- vagy 
1. táblázat. A felidézett szülôi nevelési stílus összefüggései a hipnotikus fogékonyság viselkedéses, fenomenológiai és érzelmi mutatóival az elsố vizsgálatban: többszörös lineáris regresszióelemzés $(N=196)$

\begin{tabular}{|c|c|c|c|}
\hline Kimeneti változó & Prediktor változó $(\mathrm{k})(\beta)$ & $F(\mathrm{df})$ & $R^{2}$ \\
\hline \multicolumn{4}{|l|}{ Férfiak $(n=69)$} \\
\hline WSGC Szubjektív pontszám & Anyai túlvédés $(0,261)$ & $4,914^{*}(1,67)$ & 0,054 \\
\hline PCI Disszociatív kontroll & Anyai büntetés $(0,304)$ & $6,808^{*}(1,67)$ & 0,079 \\
\hline PCI Pozitív érzelem & Anyai büntetés $(0,274)$ & $5,419^{*}(1,67)$ & 0,061 \\
\hline PCI Negatív érzelem & Anyai elutasítás $(0,247)$ & $4,348^{*}(1,67)$ & 0,047 \\
\hline PCI Vizuális képzelet & Anyai büntetés $(0,276)$ & $5,523^{*}(1,67)$ & 0,062 \\
\hline PCI Belsố folyamatokra irányuló figyelem & Anyai büntetés $(0,239)$ & $8,950^{*}(1,67)$ & 0,105 \\
\hline ABS Pozitív & Anyai büntetés $(0,239)$ & $4,077^{*}(1,67)$ & 0,043 \\
\hline ABS Negatív & Anyai elutasítás $(0,243)$ & $4,010^{*}(1,67)$ & 0,044 \\
\hline ABS Csodálat és kötôdés & Anyai büntetés $(0,248)$ & $4,113^{*}(1,63)$ & 0,046 \\
\hline ABS Félelem a negatív megítéléstôl & - & & \\
\hline ABS Függóségigény & - & & \\
\hline \multicolumn{4}{|l|}{ Nôk $(n=127)$} \\
\hline WSGC Szubjektív pontszám & - & & \\
\hline PCI Disszociatív kontroll & - & & \\
\hline PCI Pozitív érzelmek & - & & \\
\hline PCI Negatív érzelmek & $\begin{array}{l}\text { Apai érzelmi melegség } \\
(-0,381) \\
\text { Anyai érzelmi melegség } \\
(0,268) \\
\text { Anyai büntetés }(0,807) \\
\text { Anyai elutasítás }(-0,666) \\
\text { Végsố modell } \\
\end{array}$ & $8,577^{*}(4,122)$ & 0,193 \\
\hline PCI Vizuális képzelet & - & & \\
\hline PCI Belsố folyamatokra irányuló figyelem & - & & \\
\hline ABS Pozitív & - & & \\
\hline ABS Negatív & - & & \\
\hline ABS Csodálat és kötôdés & Anyai túlvédés $(-0,188)$ & $4,496^{*}(1,123)$ & 0,027 \\
\hline ABS Félelem a negatív megítéléstôl & - & & \\
\hline ABS Függőségigény & - & & \\
\hline
\end{tabular}

Megjegyzés: WSGC = Waterloo-Stanford Hipnábilitási Csoportskála. PCI = Tudat Fenomenológiája Kérdőív. ABS = Archaikus Bevonódási Skála. ${ }^{*} p<0,049$. Az International Journal of Clinical and Experimental Hypnosis engedélyével újraközölve.

kontrollváltozót nem vontunk be az elemzésbe. A második vizsgálatban azt tapasztaltuk, hogy a vizsgálati személyek korának és foglalkozásának kontrollálása növeli a modellek magyarázóerejét (Költô, 2015). Ezek az eredmények részben megerôsítik J. R. Hilgard (1979) „fejlôdési ösvények” elméletét. Ugyancsak alátámasztják kutatócsoportunk tapasztalatait, hogy a viselkedéses hipnábilitási pontszám mellett érdemes figyelembe venni az alanyok hipnózis alatti tudatmódosulásának mértékét, valamint a hipnotizôr iránti áttétel érzelmi színezetét és intenzitását is. Néhány esetben látszólag 
2. táblázat. A felidézett szülői nevelési stílus összefüggései a hipnotikus fogékonyság viselkedéses, fenomenológiai és érzelmi mutatóival a második vizsgálatban: többszörös lineáris regresszióelemzés $(N=249)$

\begin{tabular}{|c|c|c|c|}
\hline Kimeneti változó & Prediktor változó $(\mathrm{k})(\beta)$ & $F(\mathrm{df})$ & $R^{2}$ \\
\hline \multicolumn{4}{|l|}{ Férfiak $(n=105)$} \\
\hline HCsS Szubjektív pontszám & - & & \\
\hline PCI Disszociatív kontroll & - & & \\
\hline PCI Pozitív érzelmek & - & & \\
\hline PCI Negatív érzelmek & Apai büntetés $(0,225)$ & $5,517^{*}(1,103)$ & 0,042 \\
\hline PCI Vizuális képzelet & Anyai büntetés $(-0,215)$ & $5,008^{*}(1,103)$ & \\
\hline PCI Belsố folyamatokra irányuló figyelem & - & & \\
\hline ABS Pozitív & Apai büntetés $(0,292)$ & $9,614^{*}(1,103)$ & 0,076 \\
\hline ABS Negatív & Anyai büntetés $(0,430)$ & $23,359^{*}(1,103)$ & 0,177 \\
\hline ABS Csodálat és kötôdés & - & & \\
\hline ABS Félelem a negatív megítéléstôl & $\begin{array}{l}\text { Anyai büntetés }(0,305) \\
\text { Apai büntetés }(0,239) \\
\text { Végsố modell }\end{array}$ & $15,574^{*}(2,102)$ & 0,219 \\
\hline ABS Függőségigény & Apai túlvédés $(0,242)$ & $6,382^{*}(1,103)$ & 0,049 \\
\hline \multicolumn{4}{|l|}{ Nôk $(n=124)$} \\
\hline HCsS Szubjektív pontszám & $\begin{array}{l}\text { Apai érzelmi melegség } \\
(-0,206)\end{array}$ & $5,388^{*}(1,122)$ & 0,034 \\
\hline PCI Disszociatív kontroll & - & & \\
\hline PCI Pozitív érzelmek & $\begin{array}{l}\text { Apai érzelmi melegség } \\
(-0,248)\end{array}$ & $8,021^{*}(1,122)$ & 0,054 \\
\hline PCI Negatív érzelmek & Anyai büntetés $(0,218)$ & $6,080^{*}(1,122)$ & 0,040 \\
\hline PCI Vizuális képzelet & $\begin{array}{l}\text { Anyai túlvédés }(0,348) \\
\text { Apai túlvédés }(-0,260) \\
\text { Végsó modell }\end{array}$ & $5,913^{*}(2,121)$ & 0,074 \\
\hline PCI Belsố folyamatokra irányuló figyelem & Anyai túlvédés $(0,177)$ & $3,955^{*}(1,122)$ & 0,023 \\
\hline ABS Pozitív & Anyai túlvédés $(0,179)$ & $4,059^{*}(1,122)$ & 0,024 \\
\hline ABS Negatív & - & & \\
\hline ABS Csodálat és kötôdés & - & & \\
\hline ABS Félelem a negatív megítéléstôl & - & & \\
\hline ABS Függőségigény & Apai túlvédés $(0,198)$ & $4,960^{*}(1,122)$ & 0,031 \\
\hline
\end{tabular}

Megjegyzés: HCsS = Harvard Hipnábilitási Csoportskála. PCI = Tudat Fenomenológiája Kérdőív. ABS = Archaikus Bevonódási Skála. ${ }^{*} p<0,046$. Az International Journal of Clinical and Experimental Hypnosis engedélyével újraközölve.

ellentmondásos összefüggéseket találtunk, például a férfiak esetében a szülôk büntetô viselkedése elôre jelezte a pozitív archaikus bevonódást. Véleményünk szerint ez annak tulajdonítható, hogy - még laboratóriumi helyzetben is - a hipnotizốr inkább a gondoskodó, ,jó szülő” tudattalan reprezentációját mozgósítja a vizsgálati személyekben. Ennek önmagában korrektív jellege lehet, főleg akkor, ha az alany valódi szülei részérôl a gyakori büntetést és az érzelmi melegség hiányát idézi föl. Ugyanakkor az, 
hogy a hipnózisbeli érzelmek és érzelmi viszonyulás egyes dimenziói a szülők meleg és büntetố viselkedésével egyszerre összefüggenek, arra utal, hogy a hipnotizôrrel való kapcsolatban a szülók iránti ambivalens érzelmek is feléledhetnek.

\section{A szülői viselkedés és a hipnotikus bevonódás kapcsolatát az alexitimiás érzelemfeldolgozás mediálja}

A biztonságos kötôdés és a szülôkhöz füzôdô meleg, szeretetteljes kapcsolat jó felnôttkori mentalizációs készségekkel jár együtt, míg a zavart kötôdési stílus, a szülôk elhanyagoló-bántalmazó viselkedése a mentalizáció késôbbi zavaraihoz vezethet (Bateman és Fonagy, 2012). A mentalizációs készségek károsodásának egyik kifejezôdése az alexitímia, a saját érzelmi állapotok felismerésének, azonosításának és kifejezésének zavara (Taylor, Bagby és Parker, 1997). Az alexitímia bizonyítottan összefügg a szülők hideg, elhanyagoló, bántalmazó viselkedésével (Lumley, Mader, Gramzow és Papineau, 1996), valamint a pszichoterapeutától való félelemmel (Mallinckrodt, King és Coble, 1998). Ezek alapján feltételeztük, hogy a hideg-büntetô szülói viselkedés az alexitímiás érzelemfeldolgozáson keresztül befolyásolhatja a hipnózisba való bevonódást, és a hipnotikus fogékonysággal negatívan függ össze (Költô és Bányai, 2015). A Torontói Alexitímia Skála (Cserjési, Luminet és Lénárd, 2007) alkalmazásával végzett korábbi vizsgálatunk eredménye mindezt alátámasztja: az EMBU-val mért apai és anyai büntetés összefügg a hipnózisbeli negatív érzelmekkel és a félelemmel a hipnotizốr haragjától, rosszallásától, de ezt a kapcsolatot részben vagy egészben a saját érzelmek azonosításának nehézsége mediálja (a mediáció mértéke 16,9-61,6\% közötti) (Költô, 2015).

\section{TOVÁBBI KUTATÁSI IRÁNYOK: A HIPNÓZIS MINT KÖLCSÖNÖS MENTALIZÁCIÓ}

Az elmeteóriát és mentalizációt eddig kevéssé vették figyelembe a hipnózis fejlôdési szempontú értelmezésében (Kihlstrom, 2008), noha a korábbiakban említett kutatási eredmények és elméleti megfontolások is arra utalnak, hogy a jobb mentalizációs készség erôsebb hipnotikus fogékonysággal jár együtt (Bonshtein, 2012; Költô, 2015; Vandenberg, 2002; valamint l. Varga tanulmányát a jelen tematikus számban, pp. 95-112.). Azok a személyek, akik jó mentalizációs készségekkel rendelkeznek, a személyközi helyzetekben hatékonyabban képesek kiolvasni a partner mentális tartalmait, például aktuális lelkiállapotát, érzelmeit, a helyzettel kapcsolatos hiedelmeit, elvárásait. Ez a hipnózis kontextusában azt jelenti, hogy az alany pontosabban észleli, mit „vár el” tôle a hipnotizôr; nem feltétlenül abban az értelemben, hogy az alany erôsen hipnábilis legyen, inkább hogy a hipnózisban való részvétel szokásosan milyen viselkedésjegyekkel társul. A jól mentalizáló hipnotizôr pedig az interakciós szinkronitás folyamatában pontosabban észleli az alany pillanatnyi bevonódásának mértékét, és saját viselkedésének módosításával vagy gondosan megválasztott szuggesztiókkal befolyásolni, irányítani tudja azt. A hipnotizốr mentalizációs készségére vonatkozó adatokkal egyelôre nem rendelkezünk. Viszont, ahogy korábban is említettük, az alexitímiás alanyok - akiknek 
saját érzelmi állapotaik felismerése és azonosítása, tehát önmentalizációja okoz nehézséget - több negatív érzelmet (pl. félelmet és zavarodottságot) élnek át hipnózisban, és jobban félnek a hipnotizôr negatív megítélésétool. Ennek az összefüggésnek a hátterében hideg-büntetố szülối nevelésre vonatkozó emlékek álltak (Költô, 2015).

Fontos, hogy további vizsgálatoknak vessük alá a mentalizációs készségek és a hipnózisba való bevonódás összefüggését (mind az alany, mind a hipnotizôr részérôl). Ha további eredmények is igazolják, hogy a mentalizáció összefügg a hipnózisba való erôsebb bevonódással, ennek a hipnoterápiára nézve is nagy jelentósége lehet.

\section{SZÜLŐKKEL KAPCSOLATOS EMLÉKEK ÉS HIPNOTERÁPIA}

Az az eredményünk, hogy a szülői büntetés és a hipnózisbeli negatív érzelmek, illetve a hipnotizőrtôl való félelem közötti összefüggést az alexitímiás érzelemfeldolgozás mediálja, érzelmezhetô úgy, hogy a gyakran büntetett gyermek a (szülő-gyermek kapcsolatot felidézô) hipnózishelyzetben nagyobb ambivalenciát vagy félelmet él át, aminek oka érzelmi zavarodottság és a hipnotizôr (vélt) elvárásainak való megfelelés lehet. Azonban azt is láttuk, hogy szülôi hidegség-büntetés a pozitív színezetú archaikus bevonódással is összefügg, ami felveti annak lehetôségét, hogy az alany tudattalanul is „jó szülóként” látja a hipnotizôrt. Talán épp ez teremt módot arra, hogy a hipnoterápiában a valódi szülókkel kapcsolatos negatív emlékeket és a kötôdési munkamodell zavarait korrigálni tudjuk.

Mély hipnózisban a két agyfélteke közötti munkamegosztás rugalmasabbá válik, a agyféltekék múködése jobban integrálódik és a váratlan, megszokottól eltérô ingerek automatikus feldolgozása a bal (verbális) agyféltekébe tevôdik át. Erre vonatkozó pszichofiziológiai bizonyítékokat közöl a jelen tematikus számban Kasos és munkatársai tanulmánya (pp. 79-93.). Ez az agyféltekei dominanciaeltolódás teszi lehetôvé, hogy a korábban kimondhatatlan, megfogalmazhatatlan - gyakran pszichoszomatikus tünetekbe vagy betegségbe átfordított - élményeket a hipnoterápia folyamatában a kliens verbalizálni tudja (Bányai, 2015), ami révén a hipnózis az alexitímia oldásának eszköze is.

Az alany által felidézett szülókkel kapcsolatos emlékek, úgy túnik, a hipnotizórt is „megérintik”. Varga és Kekecs (2014), illetve Kasos és munkatársai (a jelen tematikus számban, pp. 79-93.) erôs negatív korrelációt talált az alanyok által felidézett (EMBU-val mért) szülői melegség és a hipnotizőrben a hipnózis során mért oxitocinfelszabadulás között. Azaz minél kevesebb melegséget idéz fel szülei visekedésével kapcsolatban az alany, annál több oxitocin termelôdik a hipnózis során a hipnotizốr szervezetében. A szerzók ezt az eredményt a szociál-pszichobiológiai elméletbe illesztik, és úgy értelmezik, hogy az alany implicit módon „magával hozza” korai kötôdési mintázatait a hipnózisba, a hipnotizórben megfigyelt oxitocintermelôdés pedig a kapcsolatteremtés, stresszcsökkentés biológiai mutatója, ami szintén hozzájárulhat a hipnoterápia korrektív szerepéhez. Az EMBU-faktorok és a hipnotizôr iránti archaikus bevonódás közötti összefüggések mintázata megerósíti ezt a feltételezést.

Láttuk azonban, hogy a gyakran büntetetett, hideg és szigorú légkörben felnevelt gyerekek számára a hipnózis félelmetes vagy negatív élmény lehet. Kezdeti eredményeink alátámasztják, hogy a hideg-büntetố szülôk gyermekei félelemtelibb attitúddel 
viseltetnek a hipnózis iránt, és a meleg-szeretetteljes szülőket felidézó vizsgálati személyeknél kevésbé hajlamosak arra, hogy önként jelentkezzenek hipnózisban való részvételre (Költô, 2017). A teherbíró, bizalmon alapuló terápiás szövetség kialakításához elengedhetetlen, hogy a terapeuta a hipnózis alkalmazása elôtt szisztematikusan vizsgálja a kliens szülőkkel kapcsolatos emlékeit, és szükség esetén a negatív emlékeket is terápiás feldolgozás tárgyává tegye.

\section{IRODALOM}

Arrindell, W. A., Sanavio, E., Aguilar, G., Sica, C., Hatzichristou, C., Eisemann, M., Recinos, L. A., Gaszner, P., Peter, M., Battagliese, G., Kállai, J., \& van der Ende, J. (1999). The development of a short form of the EMBU: Its appraisal with students in Greece, Guatemala, Hungary and Italy. Personality and Individual Differences, 27(4), 613-628.

Bachner-Melman, R., \& Lichtenberg, P. (2001). Freud's relevance to hypnosis: A reevaluation. American Journal of Clinical Hypnosis, 44(1), 37-50.

Baker, E. L. (2000). Reflections on the hypnotic relationship: Projective identification, containment, and attunement. International Journal of Clinical and Experimental Hypnosis, 48(1), $56-69$.

Bányai, É. (1998). The interactive nature of hypnosis: Research evidence for a social-psychobiological model. Contemporary Hypnosis, 15(1), 52-63.

Bányai, É. (2002). Communication in different styles of hypnosis. In C. A. L. Hoogduin, C. P. D. R. Schaap, \& H. A. A. de Berk (Eds), Issues on hypnosis (pp. 1-20). Nijmegen: Cure and Care Publishers.

Bányai É. (2008). A hipnózis szociál-pszichobiológiai modellje. In Bányai É., \& Benczúr L. (szerk.), A hipnózis és a hipnoterápia alapjai (pp. 379-445). Budapest: ELTE Eötvös Kiadó.

Bányai É. (2015). A hipnózis a kognitív és affektív idegtudomány fényében. In Vértes G. (szerk.), Hipnózis-Hipnoterápia (pp. 31-62). Budapest: Medicina Könykiadó.

Bányai É., Varga K., \& Gôsiné Greguss A. C. (2001). Szuggesztív egyéniségek: archaikus bevonódás tanárok és hipnotizőrök hatására. In Pléh Cs., László J., \& Oláh A. (szerk.), Tanulás, kezdeményezés, alkotás: Barkóczi Ilona 75. születésnapjára (pp. 313-336). Budapest: ELTE Eötvös Kiadó.

Bateman, A. W., \& Fonagy, P. (2012). Handbook of mentalizing in mental health practice. Arlington, USA: American Psychiatric Publishing.

Beauregard, M. (2014). Functional neuroimaging studies of the effects of psychotherapy. Dialogues in Clinical Neuroscience, 16(1), 75-81.

Bonshtein, U. (2012). Relational hypnosis. International Journal of Clinical and Experimental Hypnosis, 60(4), 397-415.

Bowers, K. S. (1993). The Waterloo-Stanford Group C (WSGC) Scale of Hypnotic Susceptibility: Normative and comparative data. International Journal of Clinical and Experimental Hypnosis, 41(1), 35-46.

Bowlby, J. (1979/2005). The making and breaking of affectional bonds. New York, USA: Routledge.

Butler, L. D., Duran, R. E., Jasiukaitis, P., Koopman, C., \& Spiegel, D. (1996). Hypnotizability and traumatic experience: A diathesis-stress model of dissociative symptomatology. American Journal of Psychiatry, $153(7 \mathrm{Suppl}), 42-63$.

Cserjési R., Luminet O., \& Lénárd L. (2007). A Torontói Alexitímia Skála (TAS-20) magyar változata: megbízhatósága és faktorvaliditása egyetemista mintán. Magyar Pszichológiai Szemle, 62(3), 355-368. 
Faymonville, M.-E., Boly, M., \& Laureys, S. (2006). Functional neuroanatomy of the hypnotic state. Journal of Physiology-Paris, 99(4-6), 463-469.

Ferenczi, S. (1909/2002). Introjection and transference. In J. Dupont (Ed.), First contributions to psycho-analysis: Sándor Ferenczi (pp. 35-93). London, England: H. Karnac Books Ltd.

Fonagy, P., Bateman, A., \& Bateman, A. (2011). The widening scope of mentalizing: A discussion. Psychology and Psychotherapy: Theory, Research and Practice, 84(1), 98-110.

Fonagy, P., Gergely, G., Jurist, E. L., \& Target, M. (2002). Affect regulation, mentalization, and the development of the self. New York, USA: Other Press.

Fonagy, P., Steele, M., Steele, H., Moran, G. S., \& Higgitt, A. C. (1991). The capacity for understanding mental states: The reflective self in parent and child and its significance for security of attachment. Infant Mental Health Journal, 12(3), 201-218.

Gardner, G. G. (1974). Hypnosis with children. International Journal of Clinical and Experimental Hypnosis, 22(1), 20-38.

Gardner, G. G., \& Olness, K. (1981). Hypnosis and hypnotherapy with children. New York: Grune and Stratton.

Gergely, G., \& Watson, J. S. (1996). The social biofeedback theory of parental affect-mirroring: The development of emotional self-awareness and self-control in infancy. International Journal of Psychoanalysis, 77, 1181-1212.

Gốsiné Greguss A. (1999). Waterloo-Stanford Hipnábilitási Csoportskála C forma (WSGC). Kézirat. Budapest: Eötvös Loránd Tudományegyetem Bölcsészettudományi Kar.

Gruzelier, J. H. (2006). Frontal functions, connectivity and neural efficiency underpinning hypnosis and hypnotic susceptibility. Contemporary Hypnosis, 23(1), 15-32.

Harman, C., Rothbart, M. K., \& Posner, M. I. (1997). Distress and attention interactions in early infancy. Motivation and Emotion, 21(1), 27-43.

Hilgard, E. R. (1965). Hypnotic susceptibility. Oxford, England: Harcourt, Brace \& World.

Hilgard, J. R. (1979). Personality and hypnosis: A study of imaginative involvement (2nd ed.). Chicago: University of Chicago Press.

Hilgard, J. R., \& Morgan, A. H. (1978). Treatment of anxiety and pain in childhood cancer through hypnosis. In F. H. Frankel, \& H. S. Zamansky (Eds), Hypnosis at its bicentennial: Selected papers (pp. 281-287). New York: Plenum.

Hoeft, F., Gabrieli, J. D. E., Whitfield-Gabrieli, S., Haas, B. W., Bammer, R., Menon, V., \& Spiegel, D. (2012). Functional brain basis of hypnotizability. Archives of General Psychiatry, 69(10), 1064-1072.

Kihlstrom, J. F. (2008). The domain of hypnosis, revisited. In M. R. Nash, \& A. J. Barnier (Eds), The Oxford handbook of hypnosis: Theory, research and practice (pp. 21-52). Oxford; New York: Oxford University Press.

Költô, A. (2008). A hipnotikus fogékonyság dimenziói és a szülôi nevvelési stílus. Pszichológus mesterképzés szakdolgozata. Budapest: Eötvös Loránd Tudományegyetem Pedagógiai és Pszichológiai Kar.

Költô, A. (2015). Hypnotic susceptibility and mentalization skills in the context of parental behavior. Doktori (PhD) értekezés. Budapest: Eötvös Loránd Tudományegyetem Pszichológiai Doktori Iskola. Letöltve: 2018. 12. 02-án: http://www.tinyurl.com/koltophd

Költô, A. (2017). Obstacles to hypnotic involvement. Paper presented at the XIV Congress of European Society of Hypnosis (ESH). Manchester, United Kingdom, 23-26 August 2017.

Költô A., \& Bányai É. I. (2015). Az alexitímia és a hipnotikus fogékonyság összefüggése - Szakirodalmi áttekintés. Mentálhigiéné és Pszichoszomatika, 16(1), 1-33.

Költô, A., Gôsi-Greguss, A. C., Varga, K., \& Bányai, É. I. (2015). Hungarian norms for the Harvard Group Scale of Hypnotic Susceptibility, Form A. International Journal of Clinical and Experimental Hypnosis, 63(3), 309-334. 
Költô, A., Józsa, E., \& Bányai, É. I. (in press). Recalled parental rearing style and dimensions of hypnotic response. International Journal of Clinical and Experimental Hypnosis.

Lakatos, K., \& Gervai, J. (2003). A korai kötốdés neurobiológiai háttere. In Pléh Cs., Kovács Gy., \& Gulyás B. (szerk.), Kognitív idegtudomány (pp. 326-342). Budapest: Osiris Kiadó.

Lichtenberg, P., Bachner-Melman, R., Ebstein, R. P., \& Crawford, H. J. (2004). Hypnotic susceptibility: Multidimensional relationships with Cloninger's tridimensional personality questionnaire, COMT polymorphisms, absorption, and attentional characteristics. International Journal of Clinical and Experimental Hypnosis, 52(1), 47-72.

London, P. (1965). Developmental experiments in hypnosis. Journal of Projective Techniques and Personality Assessment, 29(2), 189-199.

Lumley, M. A., Mader, C., Gramzow, J., \& Papineau, K. (1996). Family factors related to alexithymia characteristics. Psychosomatic Medicine, 58(3), 211-216.

Lynn, S. J., \& Rhue, J. W. (1988). Fantasy proneness: Hypnosis, developmental antecedents, and psychopathology. American Psychologist, 43(1), 35-44.

Mallinckrodt, B., King, J. L., \& Coble, H. M. (1998). Family dysfunction, alexithymia, and client attachment to therapist. Journal of Counseling Psychology, 45(4), 497-504.

Morgan, A. H., \& Hilgard, E. R. (1973). Age differences in susceptibility to hypnosis. International Journal of Clinical and Experimental Hypnosis, 21(2), 78-85.

Posner, M. I., \& Rothbart, M. K. (2011). Brain states and hypnosis research. Consciousness and Cognition, 20(2), 325-327.

Posner, M. I., Rothbart, M. K., \& Voelker, P. (2016). Developing brain networks of attention. Current Opinion in Pediatrics, 28(6), 720-724.

Raz, A., Fan, J., \& Posner, M. I. (2005). Hypnotic suggestion reduces conflict in the human brain. Proceedings of the National Academy of Sciences of the United States of America, 102(28), 9978-9983.

Raz, A., Shapiro, T., Fan, J., \& Posner, M. I. (2002). Hypnotic suggestion and the modulation of stroop interference. Archives of General Psychiatry, 59(12), 1155-1161.

Rhue, J. W. (2004). Developmental determinants of high hypnotizability. In M. Heap, R. J. Brown, \& D. A. Oakley (Eds), The highly hypnotizable person: Theoretical, experimental and clinical issues (pp. 115-132). Hove, United Kingdom: Brunner-Routledge.

Rhue, J. W., \& Lynn, S. J. (1987). Fantasy proneness: Developmental antecedents. Journal of Personality, 55(1), 121-137.

Shor, R. E. (1962). Three dimensions of hypnotic depth. International Journal of Clinical and Experimental Hypnosis, 10(1), 23-38.

Shor, R. E., \& Orne, E. C. (1962). Harvard Group Scale of Hypnotic Susceptibility, Form A. Palo Alto, USA: Consulting Psychologists Press.

Taylor, G. J., Bagby, R. M., \& Parker, J. D. A. (1997). Disorders of affect regulation: Alexithymia in medical and psychiatric illness. New York, USA: Cambridge University Press.

Vandenberg, B. (2002). Hypnotic responsivity from a developmental perspective: Insights from young children. International Journal of Clinical and Experimental Hypnosis, 50(3), 229-247.

Varga, K. (2017). A hipnotikus interakció fenomenológiája. Budapest: Medicina Könyvkiadó.

Varga, K., \& Kekecs, Z. (2014). Oxytocin and cortisol in the hypnotic interaction. International Journal of Clinical and Experimental Hypnosis, 62(1), 111-128.

Weitzenhoffer, A. M., \& Hilgard, E. R. (1962). Stanford Hypnotic Susceptibility Scale, Form C. Palo Alto, CA: Consulting Psychologists Press.

Winnicott, D. W. (1953). Transitional objects and transitional phenomena: A study of the first not-me possession. International Journal of Psychoanalysis, 34(2), 89-97. 


\title{
DEVELOPMENTAL AND SOCIALISATIONAL DETERMINANTS OF ADULT HYPNOTIC SUSCEPTIBILITY
}

\author{
KÖLTŐ, ANDRÁS - JÓZSA, EMESE- BÁNYAI, ÉVA
}

\begin{abstract}
The hypnotherapeutic relationship between client and therapist bear many resemblances to the relationship between child and parent. According to the social-psychobiological theory of hypnosis, adult hypnotic susceptibility is influenced by neural development and socialization. Despite this fact, so far just a few studies investigated the developmental antecedents of adult hypnotic susceptibility. Similarly, the socialisation effects were scarcely studied; the few studies in this area rather aimed to map childhood memories in a qualitative manner. In this paper we summarise the results of these studies, then we present the investigations carried out by our research team since 2008 in order to unfold the associations between recalled parental rearing style and adult hypnotic response. The main conclusion of our cross-sectional studies that employed standardised quantitative measures is that cold-punishing parental style predicts negative emotions and fear of the hypnotist's negative appraisal in laboratory hypnosis sessions. This association is partially mediated by alexithymic affective processing. These results inform the planning of hypnotherapy and reinforce the therapeutic alliance.
\end{abstract}

Keywords: parental rearing style, parental behaviour, hypnotizability, hypnotic susceptibility

A cikk a Creative Commons Attribution 4.0 International License (https:// creativecommons.org/licenses/by/4.0) feltételei szerint publikált Open Access közlemény, melynek szellemében a cikk bármilyen médiumban szabadon felhasználható, megosztható és újraközölhetô, feltéve, hogy az eredeti szerzô és a közlés helye, illetve a CC License linkje és az esetlegesen végrehajtott módosítások feltüntetésre kerülnek. (SID_1) 